\title{
Kezdeti tapasztalataink az orvos által módosított sztentgraftok alkalmazásával
}

\author{
Borzsák Sarolta dr. ${ }^{1,2}$ - Péter Csongor dr. ${ }^{1}$ - Suhai Ferenc dr. ${ }^{1}$ \\ Szeberin Zoltán dr. ${ }^{2,3}$. Csobay-Novák Csaba dr. ${ }^{1,2}$ \\ 'Semmelweis Egyetem, Általános Orvostudományi Kar, Városmajori Szív- és Érgyógyászati Klinika, \\ Intervenciós Radiológiai Tanszék, Budapest \\ ${ }^{2}$ Semmelweis Egyetem, Általános Orvostudományi Kar, Városmajori Szív- és Érgyógyászati Klinika, \\ Semmelweis Aortacentrum, Budapest \\ ${ }^{3}$ Semmelweis Egyetem, Általános Orvostudományi Kar, Városmajori Szív- és Érgyógyászati Klinika, \\ Érsebészeti és Endovaszkuláris Tanszék, Budapest
}

\begin{abstract}
Bevezetés: Az aortabetegségek kezelése során az orvos által módosított sztentgraftok alkalmazása vitatott. Döntően sürgősségi esetben, nagy rizikójú nyitott mútét alternatívájaként vagy nehéz anatómiai konfigurációk esetén alkalmazzák őket.

Módszer: Cikkünkben három eseten keresztül klinikánk kezdeti tapasztalatait mutatjuk be az orvos által a mútét során módosított sztentgraftokkal kapcsolatosan.

Eredmények: Első esetünkben egy 75 éves férfi beteg $50 \mathrm{~mm}$-es saccularis infrarenalis aortaaneurysma miatt került felvételre. A rövid infrarenalis tágulat proximalis rögzítési zónájának átmérôje lényegesen nagyobb volt, mint a terminális aortaszakasz. A kaliberdiszkrepancia megoldására a legalkalmasabb egy reverz helyzetú iliacagraftszár volt, így egy graftszárat a felvezetőrendszeréról eltávolítottunk, majd megfordítva az aorta tágulatába deponáltuk. Hasonló megoldást választottunk egy 67 éves férfi beteg jobb oldali, $65 \mathrm{~mm}$-es arteria iliaca communis aneurysmájának kezelése során. Egy 81 éves nőbeteg hasi aortaaneurysma tartott rupturája miatt korábban behelyezett unilateralis graft proximalis endoleakjének megoldása miatt érkezett. Az ectaticus aorta, valamint az arteria mesenterica superior és a primer intervenció során bekerült unilateralis graft elkeskenyedő része közti rövid távolság miatt konvencionális sztentgraft beültetése nem volt lehetséges. A szituáció egy rövid thoracalis sztentgrafttal volt megoldható: egy thoracalis sztentgraft distalis végéből $3 \mathrm{~cm}$-t kauter segítségével levágtunk, majd az eszközt a felvezetőrendszerbe visszatöltöttük. A módosított sztentgraftot az arteria mesenterica superior alá pozicionáltuk, egy 'chimney' sztentgraft segítségével biztosítottuk a jobb vese perfúzióját. Technikailag mindhárom beavatkozásunk sikeres volt.

Következtetés: Az endovascularis aortamútétek azonnal elérhető eszközparkja a típusos anatómiájú betegek megoldására általában alkalmas. A szokatlan anatómiával rendelkező elektív esetek, illetve a sürgető beavatkozást igénylő komplex endovascularis mútétek során az orvos által módosított sztentgraftok hatékonyan alkalmazhatók. Alkalmazásuk nagy forgalmú aortacentrumokban javasolt.
\end{abstract}

Orv Hetil. 2022; 163(3): 109-115.

Kulcsszavak: endovascularis technikák, abdominalis aortaaneurysma, endoleak

\section{Initial experiences with physician-modified endo grafts}

Introduction: Physician-modified endografts are mainly used in urgent cases of aortic disease as an alternative to highrisk open surgical repair or in difficult anatomical configurations.

Method: We present our initial experiences with physician-modified stent graft implantation.

Results: A 75-year-old male patient was admitted with a $50 \mathrm{~mm}$ saccular infrarenal aortic aneurysm. However, the diameter of the proximal sealing zone was significantly larger than that of the distal sealing zone, so we decided to use an iliac limb stent graft with reverse mounting resulting in an upside-down configuration to accommodate this diameter mismatch. A similar approach was used to treat a 67 -year-old male patient with a $65 \mathrm{~mm}$ right common iliac artery aneurysm. An 81-year-old female patient was admitted with a type I endoleak associated with an aortouni-iliac endograft. The wide juxtarenal aortic diameter together with the short distance between the superior mes- 
enteric artery and the proximal end of the previously deployed uni-iliac graft made the patient unsuitable for conventional endovascular repair, thus the distal $3 \mathrm{~cm}$ was cut from a standard thoracic stent graft and the device was reloaded. The modified graft was positioned below the superior mesenteric artery, while renal perfusion was secured by a chimney graft. Technical success was obtained in all three cases.

Conclusion: The available toolkit of endovascular aortic surgery is generally suitable for the treatment of patients with typical anatomy. In elective cases of patients with unusual anatomy, or in urgent cases with complex aortic pathologies, physician-modified endovascular graft implantation can be used effectively.

Keywords: endovascular techniques, abdominal aortic aneurysm, endoleak

Borzsák S, Péter Cs, Suhai F, Szeberin Z, Csobay-Novák Cs. [Initial experiences with physician-modified endo grafts]. Orv Hetil. 2022; 163(3): 109-115.

(Beérkezett: 2021. június 23.; elfogadva: 2021. július 30.)

\section{Rövidítések}

$\mathrm{CMD}=$ (custom-made device) egyedileg gyártott eszköz; $\mathrm{CT}=($ computed tomography) komputertomográfia; EVAR $=$ (endovascular aneurysm repair) az aortaaneurysma endovascularis kezelése; $\mathrm{MRA}=$ mágneses rezonanciás angiográfia; $\mathrm{OSFG}$ $=($ off-the-shelf fenestrated and branched graft) készen kapható fenesztrált és elágazó endograft; PMEG = (physician-modified endograft) orvos által módosított sztentgraft

$\mathrm{Az}$ aortaaneurysma endovascularis kezelésének (endovascular aneurysm repair - EVAR) biztonságosságát és hatékonyságát arra alkalmas aortaanatómia esetén több tanulmány igazolta, a piacon elérhető konvencionális graftok alkalmazásával az aortabetegségek többsége sikeresen kezelhető [1]. Az esetek egy jelentős hányadában azonban az anatómia nem teszi lehetővé ezen eszközök használatát. Ilyenkor - az endovascularis terápia elvetése, nyitott mütét mérlegelése mellett - egyedileg gyártott eszköz (custom-made device - CMD), készen kapható fenesztrált vagy elágazó sztentgraft (off-the-shelf fenestrated and branched stentgraft - OSFG), illetve orvos által módosított endograft alkalmazása lehetséges [2]. Ezek többek között juxtarenalis aneurysmák esetén vagy a visceralis ágakat is érintő tágulat esetén is megoldást kínálhatnak azzal, hogy suprarenalis proximalis landing zóna alkalmazására biztosítanak lehetőséget [3].

A CMD-k a páciens anatómiájához illeszkedő fenesztrált vagy elágazó sztentgraftok, melyeken megerősített fenesztrációk vagy direkt ágak figyelhetők meg a zsigeri szájadékoknak megfelelően, ezzel biztosítva a sztentgraft-implantációhoz szükséges adekvát landing zónát és a sikeres aneurysmakirekesztést [4]. Lényegesen magasabb áruk mellett jelentős hátrányuk a jellemzően hosszú gyártási idő, mely miatt gyakorlatilag csak elektív körülmények között alkalmazhatók [2].

A sürgősségi endovascularis beavatkozást igénylő betegek terápiájára OSFG-k is megjelentek a piacon, melyeken fix helyeken találhatók a visceralis ágak fenesztrációi, illetve ágai. Hatalmas előnyük az azonnali elérhetőség. Alkalmazásukat átmérőbeli diszkrepanciák és a konvencionálistól nagyban eltérő zsigeri anatómia limitálja a leginkább, emellett használatukhoz kiváló katéteres gyakorlat szükséges [2].

A CMD-k másik alternatívájaként nagyobb centrumokban az úgynevezett orvos által módosított sztentgraftok (physician-modified endograft - PMEG) alkalmazása merül fel. A PMEG kifejezés Ben Starnes nevéhez füződik, az első technikai leírás Uflacker és mtsai nevéhez köthető $[5,6]$. Ilyenkor a mútét előtt steril körülmények között egy egyenes vagy bifurkációs sztentgraftot a beavatkozást végző orvos a beteg anatómiájának megfelelően módosít. A módszer egyszerúbb változata a fordított betöltés (reverse mounting), melynek során a graftot a felvezetőrendszerről eltávolítjuk, majd fejjel lefelé implantáljuk. Bonyolultabb múveletek is elvégezhetők, kauter segítségével a visceralis szájadékoknál fenesztrációt is képezhetünk. Ígéretes módszernek tünik a szokatlan anatómiával rendelkező elektív esetek, illetve a sürgető beavatkozást igénylő komplex endovascularis mútétek esetén is, több centrum biztonságos és hatékony módszerként számol be róla [5-12]. Ugyanakkor egyik ismert hátránya, hogy a minőségkontroll a modifikációk kapcsán megszűnik. Potenciális mérési hibák, eszközkontamináció és a sztentgraft, valamint a felvezetőrendszer integritásának megváltozása egyaránt komplikációkhoz vezethet [4]. Emellett az eljárás hosszú távú sikeressége is kérdéses - valószínúleg jelentős részben ez áll annak a hátterében, hogy a magas technikai sikerarány és a jó korai eredmények ellenére a módszer nem terjedt el széles körben [13].

\section{Reverz betöltés (reverse mounting)}

A 75 éves férfi betegünk anamnéziséból a hypertonia, a nem inzulindependens diabetes mellitus, a mélyvénás thrombosis és az évtizedekkel korábban tuberkulózis miatti balvese-eltávolítás emelendő ki. Felvételére 2018 tavaszán egy $50 \mathrm{~mm}$-es saccularis infrarenalis abdominalis aortaaneurysma miatt került sor. 
Multidiszciplináris konzílium alapján endovascularis beavatkozásra készültünk. A proximalis rögzítési zóna átmérője azonban lényegesen nagyobb volt, mint a distalis, az aorta átméröinek megfelelő sztentgraft nem volt készen elérhető. Az átmérők közötti diszkrepancia megoldására reverz helyzetű iliacakomponens beültetését javasoltuk, ezt a beteg elfogadta.

A mútét során kétoldali, ultrahangvezérelt percutan femoralis punkciót követően képerősítő alatt vezettük fel a vezetődrótot az aortába. Bal oldalon merev vezetődróton egy $12 \mathrm{~F}$ kaliberú, $45 \mathrm{~cm}$ hosszúságú sheath-et (hüvelyt ) (Gore DrySeal, W. L. Gore \& Associates, Inc.; Newark, DE, USA) vezettünk az arteria (a.) renalisok szájadékáig. A reverz betöltéshez egy Gore Excluder (W. L. Gore \& Associates, Inc .) iliacakomponenst használtunk fel, melynek cranialis vége $16 \mathrm{~mm}$, distalis vége $20 \mathrm{~mm}$, hossza pedig $95 \mathrm{~mm}$ volt. A kioldózsinór elvágását, a felvezetőrendszer olívájának levágását követően a graftot a felvezetőrendszerről eltávolítottuk, majd fordított helyzetben a bal femoralis felól felvezetett merev vezetődrótra füztük. A $12 \mathrm{~F}$ sheath dilatatorának elkeskenyedő végéből mintegy $3 \mathrm{~cm}$-t levágtunk; az így kapott, tompa végű eszközt ugyancsak felfüztük a vezetődrótra, és ezzel toltuk elöre a graftot a sheath cranialis végéig. A jobb femoralis felöl végzett angiográfiával pozicionáltuk a sheath-en belül lévő graftot az a. renalis szájadékok alá. Ezt követően a graft kioldózsinórját meghúzva - még a sheath-en belül - nyitottuk a graftot, majd a sheath-ben lévő graftról a sheath-et fokozatosan hátrahúzva, a dilatatort mozdulatlanul tartva a graftot optimális pozícióban deponáltuk, egy perifériás öntáguló sztenthez hasonlóan. Így végül a beteg anatómiája számára optimális graftot helyeztünk el, melynek cranialis vége $20 \mathrm{~mm}$, caudalis vége $16 \mathrm{~mm}$ volt. A záró angiográfián szövődményt nem észleltünk. Jobb oldalon Angio-Seal (Terumo; Tokió, Japán), bal oldalon $2 \mathrm{db}$ ProGlide (Abbott; Chicago, IL, USA) eszközzel végeztünk zárást. Eseménytelen posztoperatív szakot követően a beteget a negyedik posztoperatív napon otthonába bocsátottuk. Hároméves kontroll-CT-vizsgálaton endoleak nem látszik, az aneurysmazsák zsugorodott (1. ábra).

Hasonló megoldást választottunk egy 67 éves férfi beteg jobb oldali a. iliaca communis aneurysmájának kezelése során 2019 őszén. A beteg anamnézisében myasthenia gravis, lumbalis compressiós csigolyatörés, hasfali sérv, valamint súlyos fokú aortabillentyü-stenosis szerepelt. Jobb oldali, tünetmentes, $65 \mathrm{~mm}$-es átmérőjű a. iliaca communis aneurysma miatt került felvételre, mely az a. iliaca interna eredését is érintette. Multidiszciplináris team a beteg endovascularis kezelése mellett döntött. A páciens alapbetegsége (myasthenia) miatt jódos kontrasztanyagot sem a preoperatív, sem a posztoperatív diagnosztika során nem alkalmaztunk, és az endovascularis beavatkozások alkalmával is csak neurológiai szakvéleményt követően, a minimálisan szükséges mennyiségben használtunk.

Staging beavatkozásként először a jobb a. iliaca interna embolisatióját végeztük Amplatzer dugókkal (Abbott). Később hibrid mútétet végeztünk a jobb a. femoralis feltárásából, bal oldalon percutan femoralis punkcióból. Merev vezetődrót felvezetését követően 12 F kaliberú, $45 \mathrm{~cm}$ hosszúságú DrySeal sheath-et (W. L. Gore \& Associates, Inc.) vezettünk a bifurkációig. A reverz betöltéshez egy 120 mm hosszúságú Gore Excluder (W. L. Gore \& Associates, Inc.) iliacakomponenst hasz-

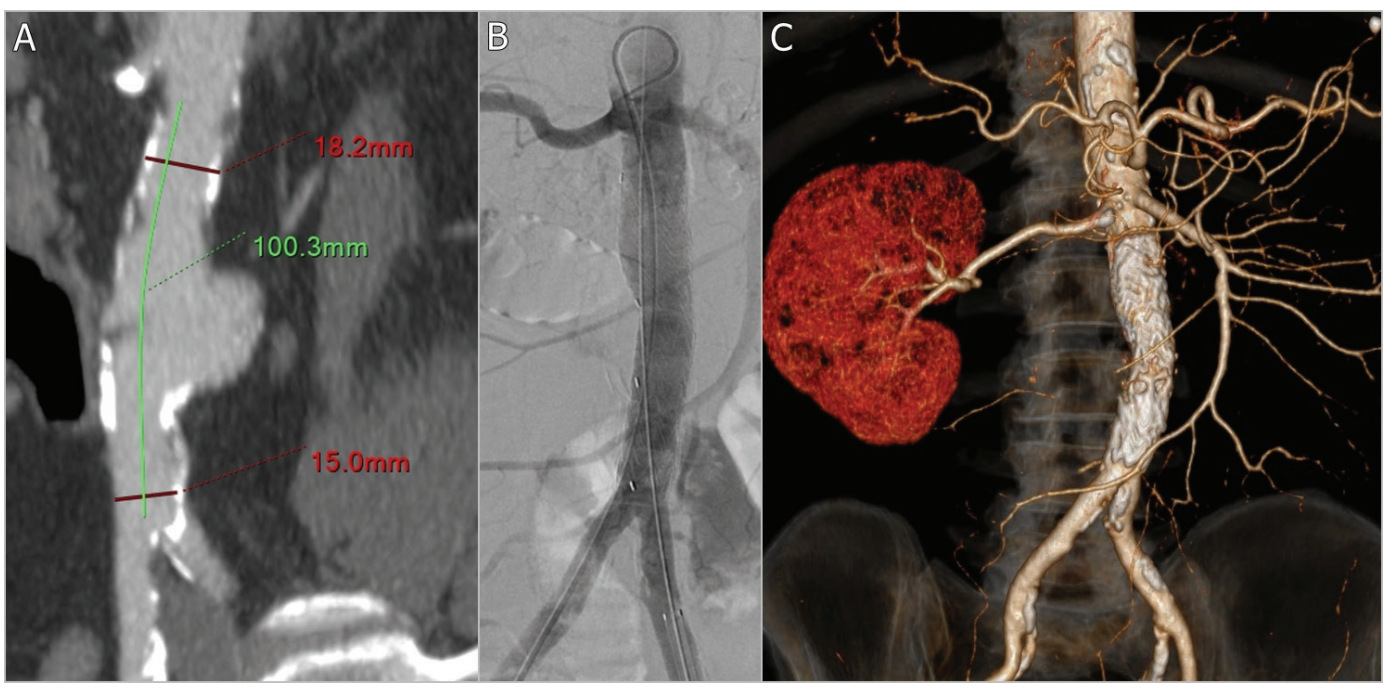

\begin{tabular}{l|l} 
1. ábra & A) Saccularis infrarenalis aortaaneurysma CT-angiográfiás felvételének multiplanáris rekonstrukciója látható, ahol a rövid infrarenalis
\end{tabular} tágulat proximalis rögzítési zónájának átméróje lényegesen nagyobb, mint a terminális aortaszakasz. B) Az endovascularis beavatkozás záró angiográfiás képén a sztentgraft homogén telődését láthatjuk, az anerysma kirekesztődött. C) A posztprocedurális CT-angiográfia háromdimenziós rekonstrukciója azonosítható, melyen az aneurysma nem telődött

CT = komputertomográfia 


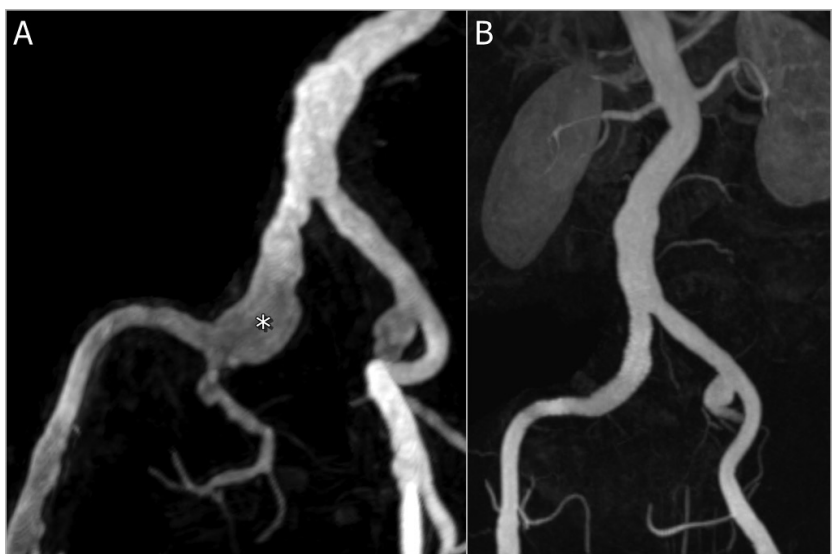

2. ábra

A) MR-angiográfiás kép a jobb oldali arteria iliaca communist érintő aneurysmáról (csillaggal jelölve). B) Az endovascularis terápiát követő kontroll-MR-angiográfiás vizsgálaton jó helyzetű sztentgraft látszódott, endoleak nem volt megfigyelhetó

$\mathrm{MR}=$ mágneses rezonancia

náltunk fel, melynek cranialis vége $16 \mathrm{~mm}$, distalis vége $20 \mathrm{~mm}$ volt. Az eszközt a fent leírtaknak megfelelően reverz betöltést követően fejjel lefelé nyitottuk. Utótágítást követően jó morfológiai eredmény ábrázolódott. A bal a. femoralist 6 F Angio-Seal VIP (Terumo) eszközzel, a jobb oldali sebet tovafutó, intracutan, felszívódó varrattal zártuk. Eseménytelen posztoperatív időszakot követően a beteget a negyedik napon otthonába bocsátottuk. A két hónap elteltével végzett MRA-vizsgálat jó helyzetû sztentgraftot mutatott endoleak nélkül (2. ábra).

\section{Sztentgraft rövidítése}

81 éves nóbetegünk anamnézisében hypertonia, szürke hályog miatti kétoldali cataractamütét és kompressziós csigolyatörés szerepelt. 2011-ben nem komplikált, atípusos, csak a hasi aortát érintő dissectio igazolódott, amelyet konzervatív módon kezeltek. 2016-ban ruptura miatt sürgősségi körülmények között unilateralis sztentgraft-implantációra és jobbról balra vezetett femorofemoralis crossover bypass implantációjára volt szükség. Utánkövetése során I/a típusú endoleak igazolódott, mely miatt proximalis kiegészítés történt egy újabb unilateralis grafttal. Perzisztáló endoleak, illetve további aneurysmazsák-növekedés miatt nonadhezív ágenssel végrehajtott embolisatio is történt, mely azonban szintén sikertelen volt.

További követése során változatlanul jelen lévő proximalis endoleak, illetve tovább táguló aneurysmazsák miatt reintervencióra kényszerültünk. Multidiszciplináris konzílium a páciens előrehaladott életkora és a nyitott mütét extrém nagy rizikója miatt endovascularis beavatkozást javasolt, melyet a beteg elfogadott.

Fenesztrált, illetve elágazó thoracoabdominalis graft implantációjára azonban az anatómiai helyzet alkalmatlan volt, a $42 \mathrm{~mm}$ átmérőjü visceralis segmentum miatt csak thoracalis sztentgraft implantációja jött szóba. Az a. mesenterica superior, illetve az unilateralis sztentgraft elkeskenyedő része közötti, mintegy 7 cm-es távolság miatt azonban a legrövidebb thoracalis sztentgraft is túl hosszú lett volna, ezért PMEG implantációja mellett döntöttünk. A renalis perfúziót párhuzamos sztentgraftokkal terveztük biztosítani 'chimney' konfigurációban.

A mútét elején steril körülmények között kinyitottunk egy $46 \mathrm{~mm}$ átmérőjü, $100 \mathrm{~mm}$ hosszúságú Valiant (Medtronic; Dublin, Írország) thoracalis sztentgraftot, majd distalis végéből két sztentsort steril kauter segítségével eltávolítottunk, végül a sztentgraftot visszatöltöttük a felvezetőrendszerbe.

Ezt követően bal a. subclavia feltárás történt a renalis sztentgraftok felvezetésére. A nagyfokú elongáció és a bal a. renalis szájadékának ismert dissectiója miatt stabil pozíciót biztosítani csak a jobb oldalon lehetett, így a bal a. renalis feláldozása mellett döntöttünk. Ezt követően jobb femoralis feltárás következett az aortasztentgraft felvezetése céljából. A sztentgraftot az a. mesenterica superior szájadéka alá pozicionáltuk, majd nyitottuk. Ezután végeztük el a jobb a. renalisba helyezett 'chimney' sztentgraft beültetését. Kontrollangiográfián a proximalis endoleak záródása látszódott a vesék megtartott perfúziójával (3. ábra).

A posztoperatív szakban szövődményt nem észleltünk, a vesefunkció nem romlott. A beteg elbocsátása előtt készített kontroll-CT-angiográfia a proximalis endoleak záródását igazolta jó helyzetű sztentgraftrendszerrel, megtartott kétoldali renalis keringéssel. A beteget jó általános állapotban otthonába bocsátottuk.

A beteg fél évvel késóbb akut, Stanford A típusú aortadissectio szövődményei miatt elhunyt.

\section{Megbeszélés}

A PMEG-k alkalmazásáról szóló publikációk javarészt esetleírások vagy retrospektív vizsgálatok, egy-két prospektív vizsgálat áll csak ez idáig rendelkezésre [14-17]. Ezek mellett két nagy elemszámú, összefoglaló tanulmány segíti a témában született jelentősebb közleményekből származó eredmények áttekintését [2, 18].

Az idén megjelent, 20 publikációt magában foglaló metaanalízis $87,5-100 \%$-os technikai sikert és $0-8 \%$-os 30 napos mortalitást írt le. A kezelés által érintett visceralis ágak tekintetében a primer átjárhatóság egy évnél 96,3-100\% volt, a 14,8 hónapos utánkövetés során 0-14,3\%-ban találtak I-es vagy III-as típusú endoleaket [18].

2012-ben Starnes retrospektív vizsgálatában 47, PMEG-beültetéssel kezelt juxtarenalis aortaaneurysma esetét dolgozta fel. A technikai sikerarány ebben a tanulmányban is magas $(98 \%)$ volt, alacsony szövődményráta mellett [5].

A legnagyobb esetszámú vizsgálatot Oderich és mtsai végezték, a 2007 és 2016 közötti időszakban történt 145 PMEG-beültetés adatait elemezték. A technikai si- 


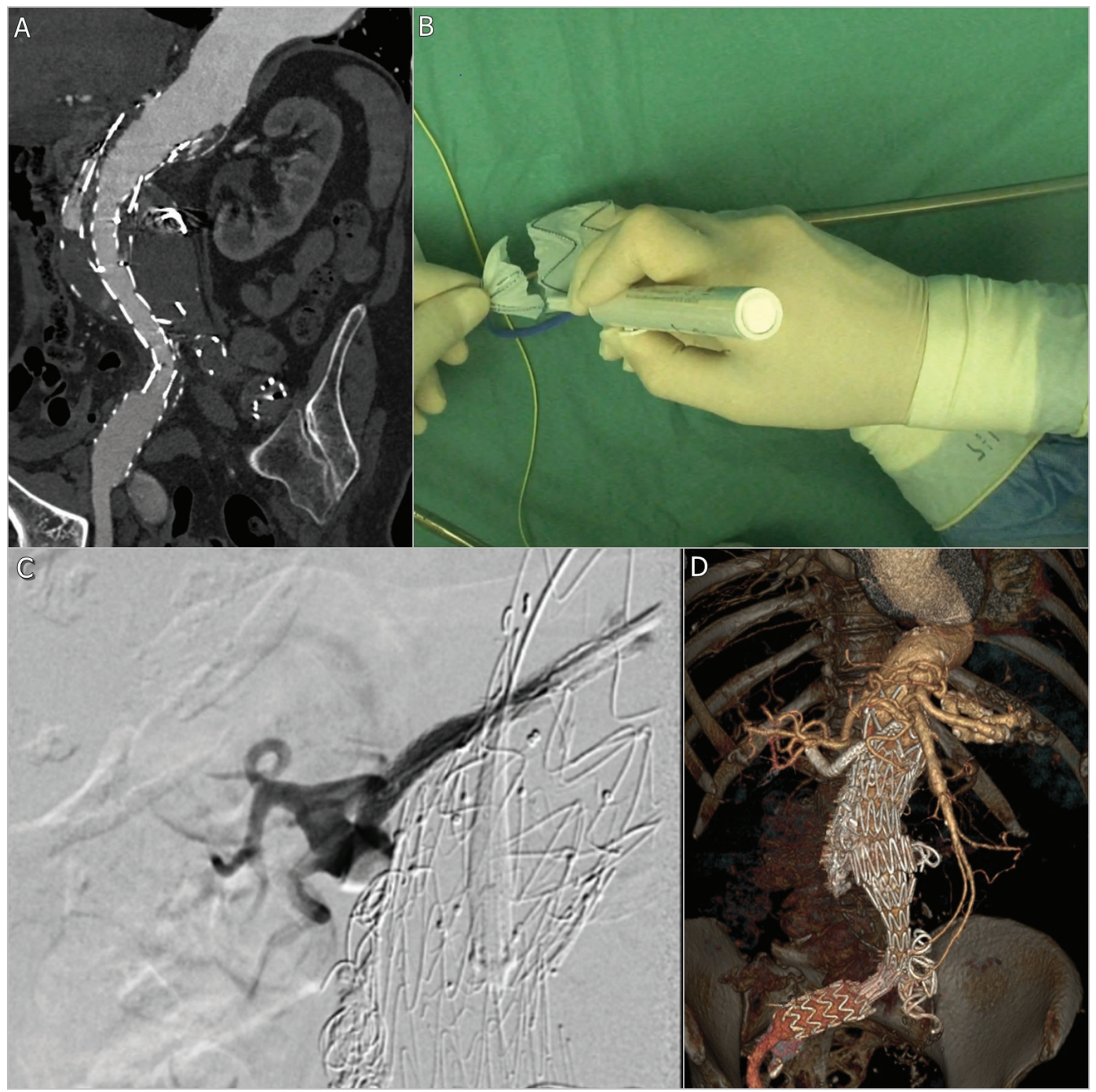

3. ábra A) Multiplanáris rekonstrukció az orvos által módosított sztentgraft behelyezése elótt készült CT-angiográfiás vizsgálatról, ahol az
aneurysmazsák mellett proximalis endoleakre utaló telódési többlet látható. B) A thoracalis sztentgraft distalis végéből két sztentsort
steril kauter segítségével eltávolítottunk. C) A jobb arteria renalisba helyezett 'chimney' sztentgraft beültetését követó angiográfín az
arteria renalison számottevó szúkület nem látszik, a jobb vese perfúziója megtartott. D) A posztprocedurális CT-angiográfia három-
dimenziós rekonstrukciója látható
CT = komputertomográfia

ker $98 \%$-os, a harmincnapos mortalitás 5,5\%-os volt. Három év elteltével 94\%-os primer és 98\%-os szekunder átjárhatóságot találtak az érintett visceralis ágak tekintetében [19].

A mi kezdeti tapasztalatunkon alapuló saját adataink ezekkel való összevetése a kis elemszám miatt nem kivitelezhető. A fent részletezett eseteinkhez hasonló jellegú technikai megoldásokra olvasható már példa az irodalomban. Leon és mtsai 2009-ben egy sikeres a. iliaca aneurysma kirekesztésről számolnak be reverz iliacagraftszár használatával [20]. Song és mtsai három izolált a. iliaca interna aneurysma kezelése során alkalmaztak reverz helyzetű iliacagraftszárat [21]. Gemayel egy instabil beteg életét veszélyeztető a. iliaca interna rupturát látott el sikeresen reverz helyzetű iliacagraftszár beültetése és embolisatio segítségével [22]. Erben és mtsai recidív coarctatio mellett jelentkező, $6 \mathrm{~cm}$-es pseudoaneurysma kap- csán alkalmaztak egyedi megoldást. Proximalisan egy invertált iliacagraftszárat, distalisan egy megfordított aortasztentgraftot ültettek be az aortába, mely „homokóra-" konfigurációt eredményezett. Az ötéves utánkövetés során komplikáció nem fordult elő, a pseudoaneurysma 61 mm-ról 25 mm-re csökkent [23]. Peppelenbosch és mtsai 12 esetet foglaltak össze különböző aortoiliacalis patológiák reverz iliacagraftszárakkal történő kezeléséról. 100\%-os közvetlen posztoperatív technikai sikert, valamint kielégítő középtávú eredményeket írtak le [24]. Van der Steenhoven és Higashigawa is sikeresen alkalmaztak infrarenalis aortaaneurysmák kezeléséhez reverz helyzetű iliacagraftszárat, hogy a fennálló átmérőbeli diszkrepanciához alkalmazkodjanak [25, 26]. Sztentgraftrövidítést Wada és mtsai alkalmaztak egy aorta ascendens pseudoaneurysma esetén. A kereskedelmi forgalomban kapható mellkasi sztentgraftok ehhez az 
eljáráshoz jellemzően túl hosszúak, ezért egy 10 cm-es sztentgraft felét levágták [27].

2018-ban Dossabhoy összevetette a PMEG-k és a CMD-k használatát. A retrospektív kohorszanalízisben 82 esetet vizsgáltak, ezekben 41, PMEG-vel és 41, gyári sztentgrafttal kezelt beteg szerepelt. Elsődleges különbségek csak a mütéti mérőszámokban és a reintervenció szükségességében látszottak. PMEG-implantáció során hosszabb fluoroszkópiás időt és mútéti időt találtak több kontrasztanyag alkalmazásával, valamint a beültetést követően több reoperációra volt szükség. A perioperatív szövődmények, a bent fekvés időtartama, az I-es vagy III-as típusú endoleak, illetve a mortalitás tekintetében nem volt kimutatható szignifikáns eltérés a két csoport között [28]. Oderich és mtsai összahasonlító vizsgálata azt mutatta, hogy a CMD-ket nagyobb technikai sikerrel (99,5\% vs. 98\%; p = 0,02), kisebb korai halálozással $(0 \%$ vs. $5,5 \% ; \mathrm{p}=0,0018)$ és kevesebb súlyos nemkívánatos eseménnyel ( $28 \%$ vs. $48 \%$; p<0,001) végezték. A hároméves túlélés és az újbóli beavatkozás nélküli túlélés hasonló volt, aneurysmával összefüggő halálozásban hoszszú távon sem találtak különbséget. Ezen eredmények értékelésekor szem előtt kell tartani a retrospektív és nem randomizált vizsgálat limitációin túl azt is, hogy a betegek jellemzően eltérő kockázati csoportba tartoztak (a PMEG-csoportban szignifikánsan nagyobb aneurysmák, több krónikus tüdő- és vesebetegség, valamint magasabb komorbiditási súlyossági pontszám volt). Ezenkívül a vizsgálat első felében többségében PMEG-t, második felében jelentős részben CMD-t használtak, így a CMD-implantációknál talált kedvező eredmények részben a beavatkozást végző orvosok tapasztalatának növekedéséből is adódhatnak [19].

Georgiadis metaanalízise is a PMEG-ket és az OFSGket hasonlította össze [2]. Bár mindkét módszert hatékonynak és biztonságosnak találta, az előbbi csoportban a klinikai siker valamelyest alacsonyabb volt $(91,4 \%$ vs. $95 \%)$, illetve a súlyos nemkívánatos események bekövetkezte $(12,8 \%$ vs. $7,4 \%)$, valamint a halálozás (3,2\% vs. $0 \%)$ kissé magasabb volt. Fontos ugyanakkor annak ismerete, hogy a PMEG-k OSFG-kkel való összehasonlíthatósága az alábbi főbb tényezők miatt limitált. Kissé eltérő az indikációs körük, részben ebből adódóan az előregyártott eszközök átlagosan több visceralis ágat inkorporálnak. Az irodalomban az orvos által módosított endograftok kapcsán észlelt kedvezőtlen kimenetelü esetek valószínúleg alulreprezentáltak. Emellett rendkívül eltérő gyakorlatú orvosok végezték a sztentgraftokon a modifikációkat, míg az OSFG-ket többnyire nagy gyakorlattal rendelkező centrumok részére biztosítottak [4]. Hazánkban OSFG-eszközök egy 'branched' graft kivételével (t-Branch; Cook Medical; Bloomington, IN, USA) nem érhetők el.

A PMEG-k szükségességét a különböző anatómiai konfigurációk jelenléte és a rövid időablakos komplex esetek ellátása egyaránt indokolja, minden bizonnyal a jövőben is jelentős szerepet játszanak majd [5]. Haszná- latukat jól bevált, hasznos technikaként tartják számon, melynek szerepelnie kell a magas kockázatú, komplex aortaaneurysmák kezelésével foglalkozó orvosok eszköztárában [4]. A thoracalis aortaszakasz PMEG-vel történő kezeléséről az utóbbi időben egyre több publikáció jelent meg [18, 29]. A PMEG-k használata az endovascularis beavatkozások tekintetében vezető egyik amerikai centrumban jelentősen csökkent, aminek hátterében a CMD-k elérhetővé válása és az 'off-the-shelf' eszközök jelentős fejlődése áll [18]. Oderich és mtsai a 2007 és 2010 közötti időszak 100\%-ához képest 2011 és 2013 között 66\%-ban, 2014 és 2016 között az esetek 4\%-ában alkalmaztak PMEG-t [19]. Ennek ellenére más országok centrumaiban a CMD-khez való korlátozott hozzáférés, illetve a PMEG-k jelentősen alacsonyabb ára miatt ezek továbbra is kiemelt jelentőséggel bírhatnak, nem csak sürgősségi helyzetekben. Elterjedtebb hazai alkalmazásuk több aortabeteg endovascularis kezelését tenné lehetővé.

Csaknem valamennyi közlemény hangsúlyozza a módszer hosszú távú sikerességének kérdésességét, melyről azonban eddig kevés adat áll rendelkezésre.

\section{Következtetés}

A típusos anatómiájú aortabetegek endovascularis kezelése mellett a komplexebb esetek endovascularis kezelésére is egyre több lehetőség kínálkozik. A PMEG-k a bonyolult anatómiai konfigurációjú betegek terápiáján túl olyan, kihívást jelentő feladatok esetén is hatékonyan alkalmazhatók, mint például a hasi aortaaneurysmák endovascularis kezelését követő proximalis rögzítési zóna tágulatával összefüggésbe hozható endoleakek ellátása. Használatukhoz elengedhetetlen a különböző eszközök és felvezetőrendszerek mélyreható ismerete és a kiváló katéteres gyakorlat. Nagy forgalmú aortacentrumokban történő alkalmazásuk az irodalmi adatok és saját kezdeti biztató tapasztalataink alapján is kedvező eredményt biztosíthat a szokatlan anatómiával rendelkező elektív esetek, illetve a sürgető beavatkozást igénylő komplex endovascularis mútétek során egyaránt.

Anyagi támogatás: A közlemény megírása, illetve a kapcsolódó kutatómunka anyagi támogatásban nem részesült.

Szerzôi munkamegosztás: A beavatkozások elvégzése: Cs.-N. Cs., Sz. Z., S. F., B. S. A képalkotó vizsgálatok elkészítése, értékelése: Cs.-N. Cs., S. F., B. S. Irodalomkutatás, a kézirat megírása, szerkesztése: B. S., P. Cs., S. F. A képek kiválasztása: B. S., S. F., Cs.-N. Cs. A kézirat átnézése, javítása, jóváhagyása: Cs.-N. Cs., S. F., Sz. Z., P. Cs. A cikk végleges változatát valamennyi szerző elolvasta és jóváhagyta.

Érdekeltségek: A szerzőknek nincsenek érdekeltségeik. 


\section{Irodalom}

[1] Wanhainen A, Verzini F, Van Herzeele I, et al. Editor s choice European Society for Vascular Surgery (ESVS) 2019 clinical practice guidelines on the management of abdominal aorto-iliac artery aneurysms. Eur J Vasc Endovasc Surg. 2019; 57: 8-93.

[2] Georgiadis GS, van Herwaarden JA, Antoniou GA, et al. Systematic review of off-the-shelf or physician-modified fenestrated and branched endografts. J Endovasc Ther. 2016; 23: 98-109.

[3] Verhoeven EL, Vourliotakis G, Bos WT, et al. Fenestrated stent grafting for short-necked and juxtarenal abdominal aortic aneurysm: an 8-year single-centre experience. Eur J Vasc Endovasc Surg. 2010; 39: 529-536.

[4] Oderich GS. Commentary: Physician-modified vs off-the-shelf fenestrated and branched endografts: is this a fair comparison? J Endovasc Ther. 2016; 23: 110-114.

[5] Starnes BW. Physician-modified endovascular grafts for the treatment of elective, symptomatic, or ruptured juxtarenal aortic aneurysms. J Vasc Surg. 2012; 56: 601-607.

[6] Uflacker R, Robison JD, Schonholz C, et al. Clinical experience with a customized fenestrated endograft for juxtarenal abdominal aortic aneurysm repair. J Vasc Interv Radiol. 2006; 17 : 1935-1942.

[7] Singh A, Mafeld S, Williams R, et al. Physician-modified fenestrated endografts for managing the ruptured or symptomatic aortic aneurysm: technique overview and clinical outcomes. Vasc Endovascular Surg. 2018; 52: 607-612.

[8] Zhu J, Zhao L, Dai X, et al. Fenestrated thoracic endovascular aortic repair using physician modified stent grafts for acute type $\mathrm{B}$ aortic dissection with unfavourable landing zone. Eur J Vasc Endovasc Surg. 2018; 55: 170-176.

[9] Anderson JL, Berce M, Hartley DE. Endoluminal aortic grafting with renal and superior mesenteric artery incorporation by graft fenestration. J Endovasc Ther. 2001; 8: 3-15.

[10] Ricotta JJ 2nd, Tsilimparis N. Surgeon-modified fenestratedbranched stent grafts to treat emergently ruptured and symptomatic complex aortic aneurysms in high-risk patients. J Vasc Surg. 2012; 56: 1535-1542.

[11] Scali ST, Waterman A, Feezor RJ, et al. Treatment of acute visceral aortic pathology with fenestrated/branched endovascular repair in high-surgical-risk patients. J Vasc Surg. 2013; 58: 5665.el.

[12] Cochennec F, Kobeiter H, Gohel M, et al. Early results of physician modified fenestrated stent grafts for the treatment of thoraco-abdominal aortic aneurysms. Eur J Vasc Endovasc Surg. 2015; 50: 583-592

[13] Sénémaud JN, Ben Abdallah I, de Boissieu P, et al. Intraoperative adverse events and early outcomes of custom-made fenestrated stent grafts and physician-modified stent grafts for complex aortic aneurysms. J Vasc Surg. 2020; 71: 1834-1842.el.

[14] Starnes BW, Tatum B. Early report from an investigator-initiated investigational device exemption clinical trial on physician-modified endovascular grafts. J Vasc Surg. 2013; 58: 311-317.

[15] Sweet MP, Starnes BW, Tatum B. Endovascular treatment of thoracoabdominal aortic aneurysm using physician-modified endografts. J Vasc Surg. 2015; 62: 1160-1167.
[16] Starnes BW, Heneghan RE, Tatum B. Midterm results from a physician-sponsored investigational device exemption clinical trial evaluating physician-modified endovascular grafts for the treatment of juxtarenal aortic aneurysms. J Vasc Surg. 2017; 65: 294-302.

[17] Mascoli C, Vezzosi M, Koutsoumpelis A, et al. Endovascular repair of acute thoraco-abdominal aortic aneurysms. Eur J Vasc Endovasc Surg. 2018; 55: 92-100.

[18] Canonge J, Jayet J, Heim F, et al. Comprehensive review of physician modified aortic stent grafts: technical and clinical outcomes. Eur J Vasc Endovasc Surg. 2021; 61: 560-569.

[19] Oderich GS, Ribeiro MS, Sandri GA, et al. Evolution from physician-modified to company-manufactured fenestrated-branched endografts to treat pararenal and thoracoabdominal aortic aneurysms. J Vasc Surg. 2019; 70: 31-42.e7.

[20] Leon LR Jr., Mills JL Sr. Successful endovascular exclusion of a common iliac artery aneurysm: off-label use of a reversed Cook Zenith extension limb stent-graft. Vasc Endovascular Surg. 2009; 43: 76-82.

[21] Song KS, Lee H, Nam DH, et al. Use of reversed iliac leg stent graft for the treatment of isolated aneurysm of internal iliac artery. Vasc Specialist Int. 2014; 30: 38-42.

[22] Gemayel G, Murith N, Kalangos A. Off-label use of a reversed flared endurant iliac limb stentgraft for the management of a lifethreatening internal iliac artery aneurysm rupture. Vascular 2014; 22: 381-384.

[23] Erben Y, Oderich GS, Duncan AA. Endovascular repair of aortic coarctation pseudoaneurysm using an off-label "hourglass" stent-graft configuration. J Endovasc Ther. 2015; 22: 460-465.

[24] Peppelenbosch AG, de Haan MW, Daemen JW, et al. Use of the reversed Zenith iliac limb extension in the treatment of iliac artery aneurysms and various aortoiliac pathologies: outcome in midterm follow-up. J Endovasc Ther. 2011; 18: 762-767.

[25] van der Steenhoven TJ, Heyligers JM, Tielliu IF, et al. The upside down Gore Excluder contralateral leg without extracorporeal predeployment for aortic or iliac aneurysm exclusion. J Vasc Surg. 2011; 53: 1738-1741.

[26] Higashigawa T, Kato N, Hashimoto T, et al. Upside down use of Gore Excluder or Cook Zenith legs. Cardiovasc Intervent Radiol. 2014; 37: 1068-1072.

[27] Wada K, Shimamoto T, Komiya T, et al. Physician modification to shorten a TAG thoracic endoprosthesis for treatment of a pseudoaneurysm in the ascending aorta. J Endovasc Ther. 2016; 23: 489-492.

[28] Dossabhoy SS, Simons JP, Flahive JM, et al. Fenestrated endovascular aortic aneurysm repair using physician-modified endovascular grafts versus company-manufactured devices. J Vasc Surg. 2018; 67: 1673-1683

[29] Han SM, Tenorio ER, Mirza AK, et al. Low-profile Zenith Alpha $^{\mathrm{TM}}$ thoracic stent graft modification using preloaded wires for urgent repair of thoracoabdominal and pararenal abdominal aortic aneurysms. Ann Vasc Surg. 2020; 67: 14-25.

(Csobay-Novák Csaba dr., Budapest, Határőr út 18., 1122 e-mail: csobay.csaba@med.semmelweis-univ.hu)

A cikk a Creative Commons Attribution 4.0 International License (https://creativecommons.org/licenses/by/4.0/) feltételei szerint publikált Open Access közlemény, melynek szellemében a cikk bármilyen médiumban szabadon felhasználható, megosztható és újraközölhetö, feltéve, hogy az eredeti szerző és a közlés helye, illetve a CC License linkje és az esetlegesen végrehajtott módosítások feltüntetésre kerülnek. (SID_1) 